\title{
PENGARUH GROWTH OPPORTUNITY, NET WORKING CAPITAL, CASH CONVERSION CYCLE DAN LEVERAGE TERHADAP CASH HOLDING PERUSAHAAN
}

\author{
Marfuah \\ Ardan Zulhilmi \\ Universitas Islam Indonesia \\ marfuah@uii.ac.id
}

\begin{abstract}
The purpose of this study was to examine the effect of growth opportunity, net working capital, cash conversion cycle and leverage on cash holding company. The population of this study are all companies listed on the Indonesia Stock Exchange from 2011 until 2013. By using purposive sampling method was selected sample of 276 over three years. Based on multiple regression analysis showed that the growth opportunity and net working capital have significant positive effect on cash holding company, while the cash conversion cycle and leverage have significant negative effect on cash holding company.
\end{abstract}

Keywords: cash holding, growth opportunity, net working capital, cash conversion cycle, leverage

\section{PENDAHULUAN}

Ketersediaan kas sangat penting bagi perusahaan terutama dalam membiayai kegiatan operasional suatu perusahaan. Memiliki kas dalam jumlah yang banyak dapat memberikan berbagai macam keuntungan bagi perusahaan seperti keuntungan dari potongan dagang (trade discount), terjaganya posisi perusahaan dalam peringkat kredit (credit rating), dan untuk membiayai kebutuhan akan kas yang tidak terduga (unexpected expenses). Dengan memiliki kas yang cukup juga sangat menguntungkan terutama pada saat terjadinya krisis kredit (seperti yang pernah terjadi di Amerika pada tahun 2007) dimana hampir semua lembaga pembiayaan sangat berhati-hati dalam mengucurkan dana kredit.

Selain keuntungan yang diperoleh melalui memegang kas dalam jumlah yang besar, terdapat
\end{abstract}

juga sisi negatifnya yaitu hilangnya kesempatan perusahaan dalam memperoleh laba karena kas bersifat idle fund artinya kas tersebut tidak memberikan pendapatan jika hanya disimpan, selain itu kas yang dipegang juga bisa berkurang karena pengaruh pengenaan pajak. Oleh karena itu masalah umum yang sering dihadapi oleh setiap manajer keuangan adalah menjalankan aktivitas bisnisnya secara reguler dengan menjaga keseimbangan jumlah kas yang ada. Dengan semakin pentingnya mengatur jumlah kas yang ideal bagi perusahaan telah menumbuhkan perhatian dari berbagai kalangan baik itu para eksekutif, analis dan investor terhadap penahanan kas (cash holdings).

Penentuan tingkat cash holding perusahaan merupakan salah satu keputusan keuangan penting yang harus diambil oleh seorang manajer keuangan. Ketika perusahaan memperoleh arus kas masuk maka manajer 
harus membuat sebuah keputusan apakah akan membagikan kepada pemegang saham berupa deviden, melakukan pembelian kembali saham, melakukan investasi atau menyimpannya untuk kepentingan perusahaan di masa depan.

Pada umumnya suatu perusahaan menginginkan tersedianya kas untuk memenuhi kebutuhan akan proyek-proyek investasi yang menguntungkan di masa mendatang. Melalui alasan ini, maka dapat dikatakan bahwa memiliki aset dalam bentuk likuid akan lebih menguntungan untuk perusahaan yang memiliki peluang investasi yang lebih besar daripada perusahaan yang memiliki ketidakpastian akan peluang investasi dikarenakan masalah keuangan yang dihadapinya (William dan Fauzi 2013). Hubungan antara growth opportunity dengan cash holdings dapat ditunjukkan melalui penelitian yang dilakukan oleh Ozkan dan Ozkan (2004) yang menemukan bahwa variabel growth opportunity berpengaruh secara signifikan terhadap cash holdings.

Variabel yang diduga juga mempengaruhi cash holding dan telah dikaji beberapa penelitian sebelumnya adalah net working capital. Net working capital mampu berperan sebagai substitusi terhadap cash holdings suatu perusahaan. Hal ini dikarenakan kemudahan dalam mengubah net working capital kedalam bentuk kas pada saat perusahaan memerlukannya. Sebagai contoh, piutang dapat dengan mudah dicairkan melalui proses sekuritisasi, hutang bank juga bisa dengan mudah diubah menjadi kas. Jadi net working capital bisa dianggap sebagai substitusi dari cash holdings. Pernyataan ini sejalan dengan penemuan Bigelli dan Vidal (2012) yang menggambarkan hubungan antara net working capital dengan cash holdings dan penelitian ini menemukan bahwa net working capital bisa berperan sebagai substitusi kas yang baik. Kim et al. (2011) menemukan bahwa perusahaan yang memiliki net working capital yang besar umumnya memegang kas dalam jumlah yang sedikit. Dengan demikian hubungan antara net working capital dengan cash holdings adalah negatip.

Variabel cash conversion cycle diduga juga mempengaruhi besarnya cash holding perusahaan, karena kecepatan perusahaan dalam menghasilkan kas ditentukan oleh lamanya proses penyelesaian cash conversion cycle. Bigelli dan Vidal (2012) menyatakan bahwa perusahaan baik sektor publik maupun swasta akan tidak begitu memerlukan kas jika mereka memiliki siklus cash conversion cycleyang yang singkat. Hubungan antara cash conversion cycle dan cash holdings lebih jelas ditunjukkan oleh penelitian yang dilakukan oleh Bigelli dan Vidal (2012) yang menunjukkan bahwa variabel net working capital, hutang bank, cash conversion cycles dan pembayaran dividen berpengaruh terhadap penentuan tingkat penahanan kas, sedangkan variabel growth opportunity tidak berpengaruh terhadap tingkat penahanan kas. Net working capital dan hutang bank dapat berfungsi sebagai pengganti kas, selanjutnya perusahaan yang memiliki siklus konversi kas yang singkat akan menahan kas dengan jumlah yang sedikit, sedangkan perusahaan yang membayar dividen cenderung memiliki jumlah kas yang lebih besar untuk membayar dividen tersebut.

Beberapa penelitian yang mengkaji factor yang mempengaruhi besarnya cash holding perusahaan di Indonesia juga telah dilakukan. Diantaranya adalah Jinkar (2013) yang menguji factor-faktor penentu kebijakan cash holding di perusahaan manufaktur yang terdaftar di BEI. Dari penelitian tersebut ditemukan bahwa variabel growth opportunity, leverage, net working capital, dan deviden payment berpengaruh terhadap cash holdings sedangkan size, cash flow dan capital expenditur tidak berpengaruh terhadap cash holding.

Penelitian Wijaya, Bandi, dan Hartoko (2010) yang menguji pengaruh kualitas akrual dan leverage terhadap cash holdings menemukan 
bahwa leverage berpengaruh negatif terhadap cash holding, sedangkan kualitas akrual tidak berpengaruh terhadap cash holding. Sementara penelitian William dan Fauzi (2013) yang menguji pengaruh growth opportunity, net working capital dan cash convension cycle terhadap cash holding menemukan bahwa growth opportunity, networking capital, dan cash conversion cycle berpengaruh terhadap cash holdings.

Penelitian ini mengacu pada penelitian William dan Fauzi (2013), namun dengan menambahkan leverage sebagai variable independen serta mengambil sampel dari perusahaan yang terdaftar di BEI pada tahun 2011 -2013, sedangkan penelitian William dan Fauzi (2013) hanya meneliti pada perusahaan sektor pertambangan yang terdaftar di BEI tahun 20092011. Diharapkan penelitian ini bisa memberikan tingkat generalisasi yang lebih luas dan mampu meningkatkan kemampuan variable independen dalam menjelaskan variasi variable dependennya. Oleh karena itu tujuan penelitian ini adalah untuk menguji pengaruh variabel growth opportunity, net working capital, cash conversion cycle dan leverage terhadap cash holding perusahaan.

\section{REVIEW LITERATUR DAN HIPOTESIS}

\section{Trade-off Theory}

Teori ini menyatakan bahwa cash holding perusahaan dikelola dengan mempertimbangkan batasan antara biaya dan manfaat (cost and benefit) yang didapatkan dalam menahan kas. Keputusan yang tepat dalam mengelola cash holding akan konsisten dengan tujuan perusahaan yaitu memaksimalkan nilai perusahaan. Menurut Keynes (1937), ada beberapa keuntungan dari cash holding yang didasarkan beberapa tipe motif dari perusahaan yang memegang kas, antara lain.

a. Transaction motive, menurut teori ini perusahaan menahan kas untuk membiayai berbagai transaksi perusahaan. Apabila perusahaan mudah mendapatkan dana dari pasar modal, cash holding tidak diperlukan namun jika tidak, maka perusahaan perlu cash holding untuk membiayai berbagai transaksi. Apabila terdapat asimetri informasi dan agency cost of debt yang tinggi akan menjadikan sumber pendanaan eksternal juga akan semakin tinggi yang menyebabkan jumlah cash holding juga menjadi semakin besar.

b. Precaution motive, menurut teori ini perusahaan memiliki cash holding dengan tujuan untuk mengantisipasi peristiwa yang tidak terduga dari aspek pembiayaan, terutama pada negara dengan perekonomian yang tidak stabil. Pasar modal akan terpengaruh oleh keadaan ekonomi yang bersifat makro seperti perubahan nilai tukar yang dapat berpengaruh terhadap nilai hutang perusahaan. Hal ini menyebabkan perusahaan memerlukan cash holding untuk mengantisipasi berbagai kemungkinan buruk perekonomian.

c. Speculation motive, teori ini menyatakan bahwa perusahaan akan menggunakan kas untuk berspekulasi mengamati berbagai kesempatan bisnis baru yang dianggap menguntungkan. Perusahaan yang sedang berkembang dapat melakukan akuisisi perusahaan lain sehingga memerlukan kas dalam jumlah besar.

d. Arbitrage motive, teori ini menyatakan bahwa perusahaan menahan kas untuk memperoleh keuntungan dari adanya berbagai perbedaan kebijakan antar negara. Perusahaan dapat mengambil dana dari pasar modal asing dengan bunga yang lebih rendah kemudian melalui mekanisme perdagangan dana tersebut ditanamkan pada pasar modal domestik yang memiliki tingkat bunga yang lebih tinggi.

\section{Pecking Order Theory}

Menurut Jinkar (2013), Pecking Order Theory mengemukakan adanya urutan sumber dana dalam pembuatan keputusan pendanaan 
perusahaan. Berdasarkan teori ini, ketika membutuhkan dana untuk keperluan pembiayaan investasi perusahaan, seharusnya perusahaan membiayai kesempatan investasi dengan dana internal terlebih dahulu. Jika keperluan untuk investasi tidak bisa didapat dari pendanaan internal, maka perusahaan akan menggunakan pendanaan eksternal dari utang sebagai sumber pendanaan kedua, dan ekuitas sebagai sumber pendanaaan terakhir. Di dalam Pecking Order Theory, kas akan menjadi buffer antara laba ditahan dan keperluan investasi.

Teori ini membuat perusahaan tidak mempunyai target kas optimal. Di dalam teori ini perusahaan tidak mempunyai tingkat optimal kas, sehingga perusahaan akan cenderung menyimpan sisa kas dari hasil kegiatan operasionalnya.

\section{Free Cash Flow Theory}

Menurut Free Cash Flow Theory, masalah akan timbul jika perusahaan memiliki free cash flow dalam jumlah besar. Pada umumnya, shareholder mengharapkan kelebihan kas tersebut didistribusikan kepada shareholder dalam bentuk dividen, sementara pihak manajemen lebih menginginkan menahan kas tersebut dengan alasan untuk keperluan pendanaan proyekproyek tertentu. Namun, terkadang manajemen termotivasi untuk melakukan kegiatan yang tidak menambah nilai bagi perusahaan dengan alasan project yang ingin diambil itu berisiko dan mengambil keuntungan perusahaan untuk kepentingan pribadinya (Opler et al, 1999).

\section{Transaction Cost Theory}

Transaction Cost Theory menjelaskan alasan mengapa perusahaan berdiri dan mengapa perusahaan memperluas aktivitasnya pada lingkungan eksternal. Coase (1937) menyatakan bahwa setiap perusahaan akan terus berkembang selama aktivitas yang dijalankan di dalam perusahaan lebih murah daripada outsourcing aktivitas tersebut kepada pihak eksternal. Teori ini memandang bahwa perusahaan akan membandingkan antara biaya pertukaran sumber daya dengan pihak eksternal dan biaya birokrasi pertukaran dalam perusahaan sendiri. Dahlman (1979) menyatakan bahwa transaction cost dapat terjadi berupa search and information cost, bargaining cost, dan policing and enforcement costs. Search dan information cost timbul dalam pengumpulan informasi mengenai ketersediaan barang yang dibutuhkan di pasar dan di tempat lain yang menjual dengan harga terendah.

\section{Penelitian Terdahulu dan Pengembangan Hipotesis \\ Pengaruh Growth Opportunity Terhadap Cash Holding}

Myers (1977) mengungkapkan bahwa growth opportunity perusahaan berhubungan dengan tingkat leverage yang digunakan oleh perusahaan. Perusahaan yang memiliki growth opportunity biasanya memiliki informational disadvantage yang berakibat pembiayaan eksternal menjadi lebih mahal. Financial distress cost menjadi lebih tinggi karena growth opportunity memiliki nature intangible dan nilainya cepat hilang saat terjadifinancial distress.

Oleh karena itu, perusahaan dengan growth opportunity yang tinggi menggunakan asset likuid (seperti kas) sebagai polis asuransi untuk mengurangi kemungkinan munculnya financial distress dan untuk mengambil kesempatan investasi yang baik terlebih dahulu saat pembiayaan eksternal mahal. Sesuai dengan pecking order theory, maka growth opportunities yang tinggi diduga akan mendorong perusahaan untuk membuat kebijakan dengan lebih memilih memegang kas yang tinggi guna membiayai kesempatan investasinya. Oleh karena itu hipotesis penelitian ini dirumuskan sebagai berikut:

H1 : Growth opportunity berpengaruh positif terhadap cash holding 


\section{Pengaruh Net Working Capital terhadap Cash Holding}

Net working capital mampu berperan sebagai substitusi terhadap cash holdings perusahaan. Hal ini dikarenakan kemudahan dalam mengubahnya ke dalam bentuk kas saat perusahaan memerlukannya. Net working capital diukur dengan membagi pengurangan current assets dan current liabilities dengan total assets. Apabila hasil net working capital negatif atau yang biasa disebut defisit modal kerja, maka perusahaan disinyalir tengah mengalami kesulitan likuiditas. Pada umumnya, perusahaan yang net working capitalnya negatif akan membuat cadangan kas. Sebaliknya jika perusahaan memiliki net working capital yang besar otomatis akan mengurangi saldo kas mereka. Argumen ini telah dibuktikan oleh penelitian Afza dan Adnan (2007), Megginson dan Wei (2010) dan Alam et al (2011). Berdasarkan uraian tersebut dan sesuai dengan trade off theory, maka dirumuskan hipotesis penelitian berikut:

H2 : Net working capital berpengaruh negatif terhadap cash holding

\section{Pengaruh Cash Conversion Cycle terhadap Cash Holding}

Cash Conversion Cycle (CCC) atau siklus konversi kas adalah waktu yang dibutuhkan perusahaan mulai dari saat perusahaan mengeluarkan uang untuk membeli bahan baku sampai dengan perusahaan mengumpulkan uang dari penjualan barang jadi. Secara teori, semakin pendek waktu yang diperlukan, semakin baik bagi perusahaan, sebaliknya, semakin panjang waktu yang diperlukan, semakin banyak modal yang harus ditanamkan.

William dan Fauzi (2013) menyatakan bahwa perusahaan baik sektor publik maupun swasta akan tidak begitu memerlukan kas jika mereka memiliki siklus konversi kas (CCC) yang singkat. Hubungan antara cash conversion cycle dan cash holding lebih jelas ditunjukkan oleh penelitian yang dilakukan oleh Bigelli dan Vidal (2012) yang menemukan bahwa perusahaan yang memiliki siklus konversi kas yang cukup lama akan cenderung memegang kas dalam jumlah yang besar. Berdasarkan uraian tersebut, dirumuskan hipotesis penelitian sebagai berikut:

H3 : Cash Conversion Cycle berpengaruh negatif terhadap cash holding

\section{Pengaruh Leverage terhadap Cash Holding}

Menurut Teruel et al. (2009), hubungan antara leverage dan cash holding adalah negatif. Hal ini dikarenakan jika perusahaan memiliki akses yang baik ke pasar obligasi dapat menggunakan hutang sebagai substitusi aktiva lancar perusahaan, meskipun sebenarnya perusahaan lebih suka memiliki kas yang tinggi dan hutang yang rendah. Perusahaan dengan hutang yang tinggi akan menggunakan hutang tersebut untuk berinvestasi sehingga jumlah kas yang dipegang menjadi kecil.

Ferreira dan Vilela (2004) menemukan bahwa perusahaan dengan tingkat leverage yang lebih besar memiliki kemampuan untuk mendapatkan pendanaan eksternal lebih mudah dan murah sehingga memungkinkan perusahaan untuk mengurangi jumlah kas yang dipegang. Bashkins (1987) berargumen bahwa opportunity cost atas investasi pada aset likuid dengan menggunakan pendanaan eksternal (hutang) meningkat. Hal ini berarti jumlah kas yang dipegang oleh perusahaan tidak lagi besar. Berdasarkan uraian tersebut dan sesuai dengan Pecking Order Theory dan Free Cash FlowTheory, dirumuskan hipotesis penelitian berikut:
H4 : leverage berpengaruh negatif terhadap cash holding

\section{Model Kerangka Penelitian}

Berdasarkan hipotesis yang dirumuskan di atas, maka hubungan antar variable penelitian digambarkan dalam model kerangka penelitian berikut: 


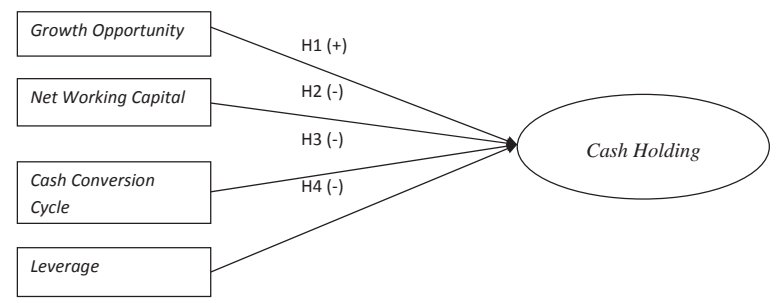

Gambar 1

Model Kerangka Penelitian

METODE PENELITIAN

\section{Populasi dan Sampel}

Populasi penelitian ini adalah seluruh perusahaan yang tercatat di BEI tahun 2011-2013. Teknik pengambilan sampel dilakukan dengan purposive sampling dengan sebagai berikut:

1. Perusahaan Manufaktur yang terdaftar di BEI secara berturut-turut periode 2011-2013.

2. Perusahaan tidak de-listing selama tahun 2011-2013.

3. Perusahaan menerbitkan laporan keuangan dalam mata uang Rupiah.

4. Periode laporan keuangan berakhir per 31 Desember.

5. Memiliki data yang lengkap untuk mengukur variable penelitian.

Berdasarkan kriteria tersebut terpilih sampel per tahun 92 perusahaan, sehingga total sampel selama 3 tahun berturut-turut adalah 276 perusahaan. Proses pemilihan sampel disajikan pada table berikut:

\section{Tabel 1}

\section{Proses Pemilihan Sampel}

\begin{tabular}{|c|l|c|}
\hline No & \multicolumn{1}{|c|}{ Kriteria } & $\begin{array}{c}\text { Jumlah } \\
\text { Perusahaan }\end{array}$ \\
\hline 1 & $\begin{array}{l}\text { Perusahaan manufaktur yang terdaftar di } \\
\text { BEI berturut-turut periode 2011-2013 }\end{array}$ & 136 \\
\hline 2 & $\begin{array}{l}\text { Perusahaan yang mengalami de-listing } \\
\text { periode 2011-2013 }\end{array}$ & $(14)$ \\
\hline 3 & $\begin{array}{l}\text { Perusahaan menerbitkan Laporan } \\
\text { Keuangan dalam mata uang asing }\end{array}$ \\
\hline 4 & $\begin{array}{l}\text { Perusahaan yang laporan keuangannya } \\
\text { tidak berakhir tanngal 31 Desember }\end{array}$ \\
\hline 5 & $\begin{array}{l}\text { Perusahaan yang tidak mempunyai } \\
\text { kelengkapan data }\end{array}$ & $(1)$ \\
\hline & Jumlah sampel per tahun & 92 \\
\hline
\end{tabular}

\section{Jenis dan Sumber Data}

Jenis data yang digunakan dalam penelitian ini adalah data sekunder berupa laporan keuangan tahunan perusahaan yang terdaftar BEI tahun 2011-2013. Data diperoleh dari www.idx. co.id.

\section{Variabel Penelitian dan Definisi Operasional}

Dalam penelitian ini ada 2 jenis variabel yang diukur, yaitu variable dependen dan independen. Variabel dependen dalam penelitian ini adalah cash holding. Menurut Teruel et al. (2009), cash holding adalah rasio keuangan yang membandingkan jumlah kas dan setara kas perusahaan dengan jumlah aktiva perusahaan. Cash holding dinotasikan dengan rumus sebagai berikut:

$$
\text { Cash Holding }=\frac{\text { Kas }+ \text { setara kas }}{\text { Total Aset }}
$$

Adapun variabel independen dalam penelitian ini terdiri dari growth opportunity, net working capital, cash conversion cycle dan leverage. Pengukuran masing-masing variable adalah:

\section{Growth Opportunity}

Menurut Huang (2005), kesempatan bertumbuh menggambarkan kenaikan (pertumbuhan) aktiva perusahaan setiap tahun. Growth opportunity diukur dengan persentase perubahan total aktiva. Formulasi growth opportunity dalam penelitian ini adalah sebagai berikut:

Growth Opportunity $=\frac{\text { Total Asset tahun } i-\text { Total Asset tahun } i-1}{\text { Total Asset tahun } i} \times 100 \%$

\section{Net Working Capital}

Net working capital merupakan total aset lancar dikurangi total liabilitas lancar. Mengacu pada penelitian William dan Fauzi (2013), notasi untuk menentukan variabel Net working capital adalah:

Net Working Capital $=\frac{\text { Aktiva Lancar - Hutang Lancar }}{\text { Total Aset }} \times 100 \%$ 


\section{Cash Conversion Cycle}

Cash conversion cycle merupakan lamanya waktu yang diperlukan dalam proses pembelian persediaan oleh perusahaan kepada supplier, proses penagihan piutang oleh perusahaan kepada pembeli dan proses pelunasan utang oleh perusahaan kepada supplier. Mengacu pada penelitian Syarief dan Wilujeng (2009), variabel Cash conversion cycles diukur dengan rumus:

Cash Conversion Cyle = Days Inventory + Days Receivable - Days Payable

1) Days Inventory $=\frac{\text { Inventory }}{\mathrm{HPP} / 365}$

2) Days Receivable $=\frac{\text { Account Receivable }}{\text { Penjualan } / 365}$

3) Days Payable $=\frac{\text { Account Payable }}{\mathrm{HPP} / 365}$

\section{Leverage}

Leverage merupakan rasio keuangan perusahaan yang membandingkan antara total hutang dengan total aktiva perusahaan. Mengacu pada penelitian Teruel et al. (2009), dalam penelitian ini leverage dinotasikan dengan rumus:

$$
\text { Laverage }=\frac{\text { Total Hutang }}{\text { Total Aktiva }}
$$

\section{Metode Analisis Data}

Pada penelitian ini, pengujian hipotesis dilakukan dengan analisis regresi linier berganda dengan model sebagai berikut:

$\mathrm{CASH}$ HOLD $=\alpha+\beta_{1}$ GROWTH $+\beta_{2} \mathrm{NWC}+$ $\beta_{3} \mathrm{CCC}+\beta_{4} \mathrm{LEV}+\varepsilon$.

Keterangan :

CASH HOLD $=$ Cash Holding.

GROWTH = Growth Opportunity

NWC = Net Working Capital

$\mathrm{CCC}=$ Cash Conversion Cycle

LEV = Leverage

$\alpha \quad=$ Intercept

$\beta_{1}, \beta_{2}, \beta_{3}, \beta_{4}=$ Koefisien Regresi

$\varepsilon=$ Error Term
Adapun kriteria pengujian hipotesis dalam penelitian ini adalah, $\mathrm{H} 0$ ditolak jika signifikansi- $\mathrm{t}$ $<\alpha$, dengan $\alpha=0.05$ dan arah koefisien regresi sesuai dengan yang diprediksi.

\section{HASIL PENELITIAN DAN PEMBAHASAN}

\section{Analisi Deskriptif}

Deskripsi data semua variable peneltian yang meliputi nilai mean, standar deviasi, maksimum dan minimum disajikan pada table berikut:

\section{Tabel 2}

\section{Statistik Deskriptif Variabel Penelitian}

\begin{tabular}{|l|r|r|r|r|r|}
\hline & \multicolumn{1}{|c|}{$\mathrm{N}$} & \multicolumn{1}{|c|}{ Minimum } & \multicolumn{1}{c|}{ Maximum } & \multicolumn{1}{c|}{ Mean } & \multicolumn{1}{c|}{ Std. Deviation } \\
\hline CASHHOLD & 276 &, 0006 &, 5003 &, 098633 &, 1165148 \\
\hline GROWTH & 276 & $-74,79$ & 100,00 & 13,6637 & 14,71021 \\
\hline NWC & 276 & $-68,14$ & 81,33 & 22,9580 & 24,60195 \\
\hline CCC & 276 & $-1170,6739$ & 869,1319 & 110,609200 & 134,7741921 \\
\hline LEV & 276 &, 0002 &, 9861 &, 463762 &, 2188242 \\
\hline
\end{tabular}

Sumber: hasil olah data

Rat-rata nilai cash holding perusahaan sebesar 0,0986 dan standar deviasi 0,1165 dengan kisaran nilai minimum dan maksimum masing-masing adalah 0,0006 dan 0,5003. Data ini mengindikasikan bahwa jumlah kas dan setara kas yang dipegang oleh perusahaan secara rata-rata sangat kecil, yaitu kurang dari $10 \%$ dari keseluruhan asset yang dimiliki oleh perusahaan dengan variasi yang sangat besar antar perusahaan.

Rata-rata nilai growth opportunity sebesar 13,6637\% dan standar deviasi 14,7102\% dengan kisaran nilai minimum dan maksimum masing-masing adalah $-74,79 \%$ dan $100 \%$. Hal ini mengindikasikan bahwa kesempatan bertumbuh perusahaan sampel masih rendah, bahkan ada perusahaan yang mempunyai tingkat pertumbuhan menurun dengan variasi yang sangat besar antar perusahaan.

Rata-rata nilai net working capital sebesar $22,9580 \%$ dan standar deviasi 24,6019\% dengan kisaran nilai minimum dan maksimum masingmasing adalah $-68,14 \%$ dan $81,33 \%$. Hal ini mengindikasikan bahwa rata-rata modal kerja bersih perusahaan masih rendah, bahkan ada 
perusahaan sampel yang mempunyai modal kerja bersh negatip dengan variasi yang sangat besar antar perusahaan.

Nilai rata-rata cash conversion cycle sebesar 110,6092 dan standar deviasi 134,7742 dengan kisaran nilai minimum dan maksimum masing-masing -1170,6739 dan 869,1319. Hal ini mengindikasikan bahwa rata-rata waktu yang diperlukan dalam proses pembelian persediaan oleh perusahaan kepada supplier, proses penagihan piutang oleh perusahaan kepada pembeli dan proses pelunasan utang oleh perusahaan kepada supplier sangat lama, yaitu melebihi 100 hari. Bahkan ada perusahaan yang mempunyai nilai cash conversion cycle negatip yang berarti perusahaan tersebut mempunyai rata-rata waktu yang diperlukan dalam proses pelunasan utang oleh perusahaan kepada supplier melebihi waktu yang diperlukan dalam proses pembelian persediaan oleh perusahaan kepada supplier dan proses penagihan piutang oleh perusahaan kepada pembeli. Variabsi data cash conversion cycle ini antar perusahaan juga sangat besar.

Rata-rata nilai leverage sebesar 0,4638 dan standar deviasi 0,2188 dengan kisaran nilai minimum dan maksimum masing-masing 0,0002 dan 0,9861. Data ini mengindikasikan bahwa rata-rata aset perusahaan yang dibiayai oleh hutang relatip rendah, yaitu kurang dari $50 \%$ dengan variasi yang sangat besar antar perusahaan. Artinya dana yang digunakan untuk mendanai aset perusahaan, sebagian besar berasal dari modal modal perusahaan.

\section{Uji Asumsi Klasik}

Pengujian regresi linear berganda dapat dilakukan setelah model lolos dari uji asumsi klasik yang meliputi uji normalitas data, uji multikolinearitas dan uji heterokedastisitas.

\section{Uji Normalitas Data}

UJi normalitas dalam penelitian ini menggunakan Kolmogrov-Smirnov Test. Hasil uji normalitas data disajikan pada tabel 3 berikut:
Tabel 3

Hasil Uji Normalitas Data

\begin{tabular}{|l|l|l|l|}
\hline Variabel & Kolmogorov Smirnov Z & Sig. (2-tailed) & Keterangan \\
\hline Residual & 1,252 & 0,087 & Normal \\
\hline
\end{tabular}

Sumber: hasil olah data

Berdasarkan hasil uji normalitas dengan Kolmogrov-Smirnov Test dihasilkan nilai asymp. sig (2-tailed) > Level of Significant $=0,05$, maka data memenuhi asumsi normalitas.

\section{Uji Heterokedastisitas}

Pendeteksian heteroskedastisitas dalam penelitian ini dilakukan dengan metode scatter plot. Berdasarkan hasil uji heteroskedastisitas dengan menggunakan scatter plot tidak ada pola yang jelas serta titik-titik menyebar ke atas dan di bawah 0 pada sumbu Y. Hal ini berarti model yang diestimasi bebas dari heteroskedastisitas.

\section{Uji Multikolinearitas}

Pendeteksian multikolinearitas dalam penelitian ini dilakukan dengan metode VIF disajikan pada tabel 4:

Tabel 4

Hasil Uji Multikolinearitas

\begin{tabular}{|l|r|r|}
\hline \multirow{2}{*}{ Variabel } & \multicolumn{2}{|c|}{ Collinearity Statistics } \\
\cline { 2 - 3 } & \multicolumn{1}{|c|}{ Tolerance } & \multicolumn{1}{c|}{ VIF } \\
\hline GROWTH &, 947 & 1,057 \\
\hline NWC &, 476 & 2,103 \\
\hline CCC &, 859 & 1,164 \\
\hline LEV &, 514 & 1,947 \\
\hline
\end{tabular}

Sumber: hasil olah data

Berdasarkan hasil uji multikolinearitas dengan metode VIF tersebut, dihasilkan nilai $\mathrm{VIF}<10$, artinya bahwa semua variabel independen tidak terjadi multikolinearitas.

\section{Hasil Pengujian Hipotesis dan Pembahasan}

Hasil pengujian hipotesis dengan menggunakan analisis regresi berganda disajikan pada table 5 di bawah ini. 
Tabel 5

Hasi Analisis Regresi Berganda

\begin{tabular}{|l|c|r|r|r|}
\hline Variabel & Prediksi & $\begin{array}{c}\text { Koefisien } \\
\text { Regresi }\end{array}$ & t-statsitik & Sig-t \\
\hline Constant & &, 0915 & 4,5440 &, 0000 \\
\hline GROWTH & $(+)$ &, 0009 & 2,5140 &, 0125 \\
\hline NWC & $(-)$ &, 0028 & 9,4900 &, 0000 \\
\hline CCC & $(-)$ &,- 0002 & $-4,4706$ &, 0000 \\
\hline LEV & $(-)$ &,- 1070 & $-3,3369$ &, 0010 \\
\hline
\end{tabular}

Sumber: hasil olah data

Secara matematis hasil analisis berganda tersebut dapat ditulis dengan persamaan berikut: CASH HOLD $=0,0915+0,0009$ GROWTH + $0,0028 \mathrm{NWC}-0,0002 \mathrm{CCC}-0,1070 \mathrm{LEV}+\varepsilon$.

Nilai Adj.R2 sebesar 0,462 menunjukkan bahwa kemampuan variable independen yang terdiri dari growth opportunity, net working capital, cash conversion cyccle dan leverage dalam menjelaskan variasi variable dependen yaitu cash holding sebesar 46,2\%. Nilai F-statistik sebesar 66,446 dengan sig-F 0,000. Hal ini mengindikasikan bahwa model regresi yang digunakan sudah lolos uji kelayakan model, sehingga hasil pengujian sig-t bisa digunakan untuk menginterpretasikan pengaruh dari setiap variable independen terhadap variable dependen. Adapun hasil pengujian pengaruh variable indeenden terhadap variable dependen dijelaskan di bawah ini.

\section{Pengaruh Growth Opportunity terhadap Cash Holding}

Variabel growth opportunity menunjukkan koefisien positif sebesar 0,0009 dengan nilai sig-t sebesar 0,0125. Hasil ini mengindikasikan bahwa growth opportunity berpengaruh positif signifikan terhadap cash holding. Oleh karena itu hipotesis 1 yang menyatakan bahwa growth opportunity berpengaruh positif terhadap cash holding didukung.

Hasil ini disebabkan karena perusahaan dengan growth opportunity yang lebih tinggi biasanya memiliki informational disadvantage yang berakibat pembiayaan eksternal menjadi lebih mahal. Oleh karena itu, perusahaan dengan growth opportunity yang tinggi menggunakan aset likuid (seperti kas) sebagai polis asuransi untuk mengurangi kemungkinan munculnya financial distress dan agar mampu mengambil investasi yang baik terlebih dahulu saat pembiayaan eksternal mahal. Hal yang perlu diperhatikan oleh perusahaan di Indonesia adalah semakin besar growth opportunity suatu perusahaan, maka semakin besar jumlah kas yang harus dipegang. Hal ini berguna untuk menghindari hilangnya kesempatan akibat keterlambatan eksekusi.

Hasil penelitian konsisten dengan temuan Jinkar (2013) yang menyatakan bahwa growth opportunity berpengaruh secara positif signifikan terhadap cash holding perusahaan.

\section{Pengaruh Net Working Capital terhadap Cash Holding}

Variabel net working capital menunjukkan koefisien positif sebesar 0,0028 dengan nilai sig-t sebesar 0,0000. Hal ini mengindikasikan bahwa net working capital berpengaruh positif signifikan terhadap cash holding. Oleh karena itu hipotesis 2 yang menyatakan bahwa net working capital berpengaruh negative terhadap cash holding tidak didukung.

Hasil yang berlawanan dengan hipotesis 2 yang diajukan kemungkinan disebabkan karena kas merupakan bagian dari net working capital sehingga pada saat kas meningkat, net working capital juga meningkat. Selain itu, aset lancar selain kas tidak dapat menjadi subtitusi bagi kas di setiap saat. Pada beberapa kondisi khusus (sebagai contoh pada saat krisis), aset lancar tidak dapat diubah menjadi kas dengan mudah. Oleh sebab itu, para manajer perusahaan biasanya membuat cadangan kas guna menjaga likuiditas. Hal ini sangat penting karena apabila terjadi economy shock, kas dan aset lancar bisa menjadi penyelamat perusahaan dari ancaman kebangkrutan (Jinkar, 2013). Hasil penelitian 
ini sesuai dengan temuan Jinkar (2013) yang menyimpulkan bahwa net working capital berpengaruh secara positif signifikan terhadap cash holding perusahaan

\section{Pengaruh Cash Conversion Cycle terhadap Cash Holding}

Variabel cash conversion cycle menunjukkan koefisien negatif sebesar -0,0002 dengan nilai sig-t 0,0000. Hasil ini mengindikasikan bahwa cash conversion cycle berpengaruh negatif signifikan terhadap cash holding. Oleh karena itu hipotesis 3 yang menyatakan bahwa cash conversion cycle berpengaruh negatif terhadap cash holding didukung.

Perputaran kas yang tercermin dari siklus konversi kas akan mempengaruhi saldo kas pada waktu tertentu. Semakin pendek periode dalam proses perputaran kas maka semakin cepat cash turnover yang dihasilkannya, dan sebaliknya. Dengan semakin cepat cash turnover maka perusahaan akan meminimumkan saldo kas pada perusahaan, karena cash turnover tersebut bisa berperan sebagai medium pembiayaan aktivitas operasional. Sebaliknya perusahaan yang memiliki siklus konversi kas yang panjang umumnya memiliki saldo kas dalam jumlah yang besar. Oleh sebab itu, besar kecilnya jumlah kas yang dipegang oleh suatu perusahaan juga bergantung pada lamanya proses cash conversion cycle. Hasil penelitian konsisten dengan penelitian William dan Fauzi (2013) yang menemukan bahwa cash conversion cycle berpengaruh negatif signifikan terhadap cash holding perusahaan.

\section{Pengaruh Leverage terhadap Cash Holding}

Variabel leverage menunjukkan koefisien negatif sebesar -0,1070 dengan nilai sig-t 0,0010. Hasil ini mengindikasikan bahwa leverage berpengaruh negatif signifikan terhadap cash holding. Oleh karena itu hipotesis 4 yang menyatakan bahwa leverage berpengaruh negatif terhadap cash holding didukung. Hal ini menunjukkan bahwa leverage yang besar menunjukkan kekuatan perusahaan menuju akses sumber pembiayaan perusahaan. Perusahaan yang memiliki dukungan hutang yang kuat dalam sumber pendanaannya, tidak perlu memegang kas dalam jumlah besar karena hutang dapat menjadi substitusi bagi kas perusahaan untuk membiayai berbagai aktivitas perusahaan Hasil penelitian sesuai dengan penelitian Wijaya, Bandi dan Hartoko (2010) yang menemukan bahwa leverage berpengaruh negatip signifikan terhadap cash holding perusahaan.

\section{KESIMPULAN DAN SARAN}

\section{Kesimpulan}

Penelitian ini bertujuan untuk menguji pengaruh growth opportunity, net working capital, cash conversion cycle dan leverage terhadap cash holding perusahaan. Berdasarkan analisis regresi linear berganda bisa disimpulkan bahwa dari empat hipotesis yang diajukan, ketiga hipotesis yaitu hipotesis 1, 3, dan 4 didukung, sedangkan hipotesis ke 2 hasilnya berlawanan arah dengan yang diprediksi. Berikut kesimpulan dari setiap pengujian hipotesis:

1. Growth opportunity berpengaruh positif terhadap cash holding. Hal ini menunjukkan bahwa perusahaan yang memiliki growth opportunity yang tinggi biasanya akan menjaga agar kesempatan tersebut tidak terlewatkan begitu saja sehingga untuk berjaga-jaga perusahaan tersebut biasanya akan membuat cadangan kas yang cukup besar sampai kesempatan dapat dieksekusi dan memberi nilai tambah bagi perusahaan.

2. Net working capital berpengaruh positif terhadap cash holding. Hal ini dapat diartikan bahwa tinggi rendahnya net working capital akan mempengaruhi tingginya cash holding perusahaan. Hal ini dimungkinkan karena aset lancar selain kas tidak dapat menjadi subtitusi bagi kas di setiap saat. Contohnya pada saat krisis, aset lancar tidak dapat diubah menjadi kas dengan mudah. 
3. Cash conversion cycle berpengaruh negatif terhadap cash holding. Hal ini mengindikasikan bahwa apabila perusahaan dengan siklus konversi kas yang lama akan menyimpan kas dalam jumlah yang besar. Sebaliknya jika siklus konversi kas perusahaan lebih singkat maka kas yang disimpan perusahaan juga akan sedikit.

4. Leverage berpengaruh negatif terhadap cash holding. Hal ini menunjukkan bahwa semakin tinggi tingkat leverage maka akan semakin rendah cash holding perusahaan. Jika perusahaan dapat dengan mudah memperoleh sumber pendanaan dari hutang maka perusahaan dapat menahan kas dalam jumlah yang rendah.

\section{Saran}

Penelitian ini hanya menguji 4 variabel independen yaitu growth opportunity, net working capital, cash conversion cycle dan leverage, sedangkan kemungkinan masih banyak variabel lain yang juga mempengaruhi cash holding. Perusahaan yang menjadi sampel hanya mengambil perusahaan manufaktur secara keseluruhan sehingga hasil penelitian ini tidak dapat menjelaskan lebih detail setiap sub sektor perusahaan yang ada di dalam sektor manufaktur tersebut. Karena keterbatasan di atas maka yang dapat disarankan adalah :

1. Peneliti selanjutnya bisa menambahkan variabel independen lain yang kemungkinan mempengaruhi cash holding perusahaan, seperti ukuran perusahaan, profitability, dividen pyment dan corporate governance.

2. Peneliti selanjutnya diharapkan mmenganalisis cash holding pada semua sub sektor perusahaan yang ada dalam sektor manufaktur, seperti sektor industri dasar dan kimia, sektor aneka industri dan sektor industri barang konsumsi agar bisa diperoleh gambaran yang detail dan dapat diperbandingkan praktek pengelolaan cash holding.

\section{DAFTAR PUSTAKA}

Bigelli, M., Vidal, J.S., 2012.Cash Holdings in Private Firms.Journal of Banking \& Finance Vol 36, 26-35.

Christina, Yessica Tria, dan Ekawati, Erni. 2014. Excess Cash Holdings dan Kepemilikan Institusional pada Perusahaan Mahufaktur yang terdaftar di BEI. Jurnal Manajemen Strategi Bisnis dan Kewirausahaan, Vol. 8, No. 1

Fatmasari, Rini. 2011. Hubungan Antara Growth Opportunity dengan Debt Maturity dan Kebijakan Leverage Serta Fungsi Covenant dalam Mengontrol Konflik Keagenan Antara Shareholders dengan Debtholders. Buletin Ekonomi Moneter dan Perbankan.

Harahap, Ludwina, dan Wardhani, Ratna. 2012. Analisis Komprehensif Pengaruh Family Ownership, Masalah Keagenan, Kebijakan Dividen, Kebijakan Hutang, Corporate Governance dan Opportunity Growth Terhadap Nilai Perusahaan. Simposium Nasional Akuntansi, Vol. 15.

IAI. "Pernyataan Standar Akuntansi Keuangan No. 2: Kas dan Setara Kas, IAI,Jakarta, 2009.

Jensen, Michael C. dan Meckling, William H.. 1976.Theory of the Firm: Managerial Behavior,Agency Costs and Ownership Structure. Journal of Financial Economics, Vol. 3, No. 4, Hal.305-360.

Jinkar, Rebecca Theresia. 2013. Analisa Faktorfaktor Penentu Kebijakan Cash Holding Perusahaan Manufaktur di Indonesia. Mini Economica, Edisi 42,: 129-146, ISSN: 0216-971.

Mamduh Hanafi, 2005, Manajemen Keuangan, Edisi Pertama. Jogjakarta: BPFE UGM.

Opler, T., L. Pinkowitz, R. Stulz, and R. Williamson. 1999. The Determinants and Implications of Corporate Cash 
Holdings. Journal of Financial Economics, 52 (1), 3-46.

Ozkan, Aydin and Neslihan Ozkan. 2004. Corporate Cash Holdings: An Empirical Investigation of UK Companies. Journal of Banking and Finance, 28 (9), 21032134.

Sari, Ira Prawita, dan Januarti, Indira. 2011. Pengaruh Growth Opportunity Terhadap Leverage dengan Debt Covenant sebagai Variabel Moderating. Seminar Nasional Ilmu Ekonomi Terapan..

Syarief, Moch. Edman, dan Wilujeng, Ita Prihatining. 2009. Cash Conversion Cycle dan Hubungannya dengan Ukuran Perusahaan, Profitabilitas dan Manajemen Modal Kerja. Jurnal Ekonomi Bisnis, Nomor 1.

Teruel et al, 2009. Accruals Quality and Corporate Cash Holdings. Journal compilation Accounting and Finance, 49 (1), 95-115.

Weston J., Copelan Thomas E., 1997. Manajemen Keuangan, Edisi ke-8, Raja Grafindo Persada.
Weston J. Fred dan Eugene F. Brigham, 1994, Dasar-dasar Manajemen Keuangan, Edisi Kesembilan. Jakarta: Erlangga.

Wijaya, Anggita Langgeng. 2011. Perbedaan cash holding pada perusahaan dengan leverage tinggi dan rendah. Jurnal Reviu Akuntansi dan Keuangan ISSN: 20880685, Vol. 1, No. 1, hal 57-62.

Wijaya, Anggita Langgeng, Bandi, dan Hartoko, Sri. 2010. Pengaruh Kualitas Akrual dan Leverage Terhadap Cash Holding Perusahaan.Jurnal Akuntansi dan Keuangan Indonesia, Volume 7, No. 2, Hal 170-186

William, dan Fauzi, Syarief. 2013. Analisis Pengaruh Growth Opportunity, Net Working Capital, dan Cash Conversion Cycle Terhadap Cash Holdings Perusahaan Sektor Pertambangan. Jurnal Ekonomi dan Keuangan, Vol. 1, No. 2.

www.idx.co.id (diakses pada 10 Oktober 2014, 23.45)

www.sahamok.com (diakses pada 10 Oktober 2014, 00.19) 